\title{
RESISTÊNCIA MECÂNICA RESIDUAL DO CONCRETO SOB ELEVADAS TEMPERATURAS EM FUNÇÃO DO TIPO DE AGREGADO
}

\author{
Danielle C. Camargo*, Isabela J. Rosa*, Lethicia O. Lima*, Jaqueline R. M. Rosetto*, Nilton Cunha*; Armando L. \\ Moreno $\mathrm{Jr}^{\star}$
}

\section{Resumo}

Edificações em concreto tem sua resistência mecânica reduzida quando submetidas a temperaturas elevadas. Podem, inclusive, ter pedaços de seus elementos destacados, de maneira explosiva, durante um incêndio; fenômeno denominado "spalling". A resistência mecânica residual (RR) do concreto após aquecimento, bem como o spalling, são influenciados por parâmetros, intrínsecos às propriedades geométricas, mecânicas, físicas e térmicas, destacando-se os tipos e proporções entre os materiais componentes da mistura, a porosidade, a densidade, o teor de umidade, entre outros. Essa pesquisa teve o objetivo de avaliar a influência do tipo de agregado graúdo sobre o comportamento do concreto quando submetido à situação de incêndio. Amostras de concreto foram moldadas e submetidas a temperaturas elevadas. Após resfriamento, estas foram avaliadas em relação à RR e à tendência ao lascamento explosivo.

Palavras-chave: Concreto, Incêndio, Spalling.

\section{Introdução}

O concreto é o material mais utilizado atualmente na construção civil. É composto por cimento Portland, agregados graúdo (brita) e miúdo (areia) e água. Possui um bom desempenho em relação à resistência ao fogo, por não ser inflamável e conseguir preservar suas propriedades mecânicas por um período razoável de tempo (ABCP, 2002). Entretanto, quando aquecido, o concreto perde resistência mecânica e fica sujeito a lascamentos explosivos; fenômeno denominado spalling. Avaliar a intensidade dessa redução de resistência e a intensidade de eventual lascamento explosivo é necessário como forma de garantir a segurança das estruturas de concreto ao fogo.

\section{Resultados e Discussão}

Utilizou-se os agregados graúdos basalto (B) e granito (G) na produção de concreto e as classes de resistência (fck): (I) 20 a $35 \mathrm{MPa}$; (II), 35 à $55 \mathrm{MPa}$ e (III), acima de $55 \mathrm{MPa}$. A resistência à compressão $(\mathrm{RC})$ foi obtida nas idades de 7, 28 e 56 dias. Aos 100 dias as amostras foram submetidas a elevadas temperaturas (Curva ISO834 por 1 hora). Após essa etapa, avaliou-se a resistência residual (RR), índice de fissuras (IF), perda de massa (PM) e spalling. Para os ensaios de RC e RR foram utilizados cilindros $(100 \times 200 \mathrm{~mm})$ e para os demais ensaios usou-se placas de $150 \times 150 \times 100 \mathrm{~mm}$.

A partir dos dados apresentados na Tabela 1, observase que as amostras de granito apresentaram maior redução da RR e maiores IF e PM do que as amostras confeccionadas com basalto.
Tabela 1: Resumo dos resultados obtidos.

\begin{tabular}{|c|c|c|c|c|}
\hline Amostra & $\begin{array}{c}\text { RC 28 } \\
\text { dias } \\
\text { (MPa) }\end{array}$ & $\begin{array}{c}\text { RR } \\
\text { (MPa) }\end{array}$ & $\begin{array}{c}\text { IF } \\
\text { (m/m²) }\end{array}$ & $\begin{array}{c}\text { PM } \\
\text { (\%) }\end{array}$ \\
\hline IB & 28,60 & 20,63 & 45,78 & 3,07 \\
\hline IG & 30,81 & 21,58 & 60,18 & 1,52 \\
\hline IIB & 54,69 & 25,40 & 60,99 & 2,51 \\
\hline IIG & 43,16 & 19,16 & 81,00 & 3,27 \\
\hline & & \\
\hline
\end{tabular}

Figura 1: Forno utilizado na simulação de incêndio e as mostras pós- incêndio.

\section{Conclusões}

○ tipo de agregado graúdo interfere diretamente no comportamento do concreto quando exposto a elevadas temperaturas. Essa influência é mais acentuada para concretos com resistências mecânicas maiores.

\section{Agradecimento}

Agradecemos à PRP pela oportunidade e ao CNPQ pelas bolsas concedidas.

Associação Brasileira de Cimento Portland, ABCP- Boletim técnicoGuia básico de utilização do cimento Portland-São Paulo,2002; 